\title{
Water history and the modern
}

\author{
Johann Tempelhoff $\cdot$ Heather Hoag $\cdot$ Maurits Ertsen
}

Published online: 10 December 2009

(C) The Author(s) 2009. This article is published with open access at Springerlink.com

Amid the many environmental problems facing societies worldwide-climate change, scarcity of natural resources, pollution, habitat destruction-water is paramount. The debate over water management brings together national and local governments, managers and engineers, and industrial and domestic users. Who should decide how water resources are developed and distributed? This question is not a new one. Historicizing a society's relationship to water is crucial in understanding present debates about water. After all, the different ways people perceived, valued, and used water and how water infrastructure was developed to support these perspectives has influenced modern society. As we stated in the first issue, problems and/or concerns in water development in the past relate directly and indirectly to contemporary issues. Drawing analogies between past and present events may yield similarities that can have a profound effect on current water-related decision making. The historical perspective, by providing context, the longue durée, and useful case studies, invites today's managers to think more creatively about water.

In this issue, our focus is on modern water histories. In the first contribution, Evy Håland explores the role of water in both modern and ancient Greece. She argues that contemporary Greek water rituals are related to and based on ancient pre-Christian traditions. Certain sites, like the springs in the caves she describes, have continued to be important locations of water rituals. Through an analysis of these water-focused religious rituals, she illustrates the value both ancient and modern believers place on water purity and its healing power. Drawing upon anthropological, archeological, and historical methods and sources, Håland situates modern practice within the deeper historical context and shows the continuous association of water sources with sacred practices in Greece.

The final two articles address what is perhaps the most pervasive symbol of human technical control of water: the dam. The conversion of water into electricity has been a central and contentious component of modern industrial development. Janet MartinNielsen examines the political and economic debates about the export of hydropower from Canada to the United States between 1900 and 1925. She analyzes the legislation

J. Tempelhoff $(\bowtie) \cdot$ H. Hoag $\cdot$ M. Ertsen

Department of Civil Engineering and Geosciences, Delft University of Technology, Stevinweg 1, PO Box 5048, 2628 CN Delft, The Netherlands

e-mail: M.W.Ertsen@tudelft.nl 
regulating international transfers of hydropower in the context of the conflicting perspectives of politicians and engineers. Public concern over power rationing and national fears of being dominated by the United States led key government actors to regulate closely electricity sales. Martin-Nielson argues that due to their training and societal position engineers tended to evaluate risks differently from the general public, and thus saw energy sales as a rational use of Canada's abundant water resources. Therefore, some engineers continued to advocate in favor of the export of hydroelectricity. The case shows how political factors and engineering paradigms affected the development of Canada's hydropower industry and, at times, influenced transnational relationships.

Since the 1990s, concern over the negative environmental impact of dams has led to a growing movement to remove or re-engineer dams so as to restore fisheries and riverine ecosystems. The final paper by Jeff Crane crosses the border to present the case of the Edwards Dam, on Maine's Kennebec River (United States). He argues that the removal of the dam in 1999 was the culmination of decades of advocacy on the part of local environmental groups, residents, and fish biologists and ultimately assisted the growth of dam removal efforts throughout the U.S. The case further illustrates the changing values societies place on water resources and how the interplay of economic, cultural, and political interests has shaped modern approaches to water management.

Together the three papers show that understanding the "modern" should go hand in hand with understanding the "past". Recognizing this need may not immediately lead to improvements in current water policies, designs, or practices, but understanding both the intangible (perceptions and beliefs) and the tangible (infrastructure and legislation) aspects of water history is an important first step to better management of today's water resources.

Open Access This article is distributed under the terms of the Creative Commons Attribution Noncommercial License which permits any noncommercial use, distribution, and reproduction in any medium, provided the original author(s) and source are credited. 